Michael R. Maier, Staniey R. 01son, Michiyuki Naksirura and Frederick $S$. Coulding

\title{
October 1978
}

Prepared for the U. S. Department of Energy under Contract H-7405-ERG-48
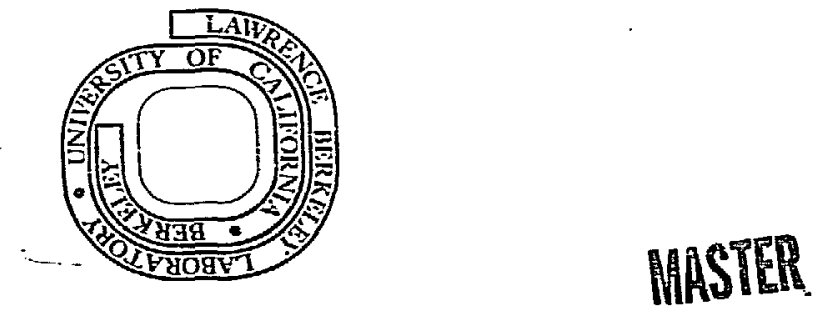


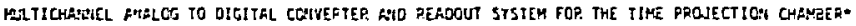

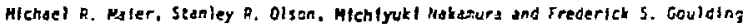

\section{Asstract}

The Itre frojection chezter (TDC) praject involves the charbcterization of sicndis erriuting at approxiadely 20, Cro separze zetector wires and pad electrodas. ine characterizaticn require: redsurecent of the signal erplicures in 100 ns rite slices over d totil tiaf of 20 ; the total charber crift

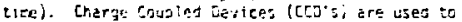

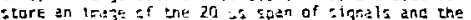

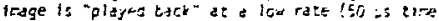
sllces, f.e.. a ties erpension of soj:11. Digitization of the 20.000 parallel sicnals at the output

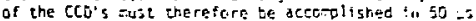

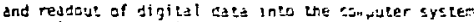
Eust slso te eccorplished in this the. "ory ceros oceur in the dat, a fact which $r$ teure: the cata hardling candes on tha rfacts:

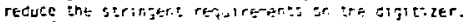
Therefore, the rewulereres on pe digitizer ete highlighted by the need for law cost. led pater consuption and of tha naxs io perfort g-bit digitizing

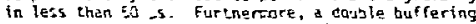
schere cas $t=0$ weo to perit interleaving digizizjing and digital readout cycles.

He describe our ifoiecentation of this concept and sore possible applications for other experipents wich require rany Aralog to Digital Converter (ADC) channels.

\section{Introduction}

The central elecent of the PEP-4 det:ctor at the PEP storage ring as Stanford, Califormia. is the TPC. It is a large volue drift chezber. a cylinder of 2 a diaseter znd 2 a long. wich provides intrinsically three dicensiond spetial data. The chater is shom scheretically in Fig. 1 . It is in a 1.5 tesla solfroidal regnetic field. and is filled with a rixture of $00:$ argan end $20 \%$ thane at a pressure of 10 atrospheres. A voltage of approxicately $150 \mathrm{kV}$ Is applied to the center plene to produce an electric field wich drifts the electrons prosuted by periticle tracks in the chaber to tne position sensivive proportional-wire detectors at tre tho end caps. Each end cap is equiposd vith sil secture go fosition sensing efecters.-wires at positi ie yoltage, wich serve as proportional counters to 201 ify the charge reaching tia wires by a factor of thout 1000. The wre sichals gitie inforaticr cn the rediel distance (r) of a treck fros tha centerline. There are Ig? of these "de/tw-wires" per seftor. In adticion there are 12 wires distritutes over the secter, micic cive the ezifuthal angla (i) of the sracks.

This angle inforation carived from a row of seall (7 cti $\times 7$ as) pads placed tencer thase wires, cn with the avalenche co the wire induces sicnals. irese signels can be used to deterwine the centroid of the avalanche. The coorcinate ziong ent bes axis (Z) is derived ira the tire of artival af th: chare frou the Erachs following e start signel derived frow the rep bean signals.
The signal alltudes on the CE/tex wire teteraine the energy-loss pattem dlong the treck. Fie caqne:lc fielo servies prirartiy to cageraire the comentue of the particle, by zescurerent of the curvalure of the eracks, Dut it else recuces the trentverse spreading of electrons asring the crift groseis. The sumaticn of all these cera diliows identificetion of the ceny particles profuced in very hipr-erterny interctions and cateraties their energies ens

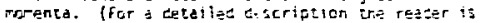
referred to fef. 1.)

Simply stated. Tfe required a systar capecle of

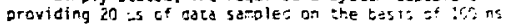

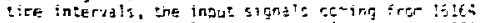
sources. This arystales to a tciel of tnres ailition

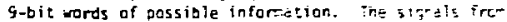
the wirss feed lad-noize-charge-sensizide jrestzi-iters.

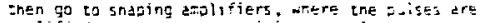
eplified and srapec to gptizize si r.el-ic-or:te ratios. The resulting sigris ere :-nn $52-p$ ied and stored in CCO's which are name ily deing ctrected at

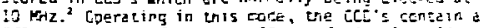
"flash picture" of the past 20 as of signifis silit into $109 \mathrm{~ns}$ tire segrents. Wiren en Event $i s$ tetertes by suitable trigger electrontcs, the cen cisct rete is slared tom, and the alolitude infarmetien naw residing in the CCD's is shiftse to gheir ojtout at a $20 \mathrm{kHz}$ rate. Digitizetian of signa is and eranser of the digitized stgna is to ithe cajucter gectessing systen cust therefore be acccop? ished fo less than 50 us (i.e. one CCO slex clcci cycilel. This fager describes the A-D-convertor sesign used in tait application. It aiso discisses the methoc eppleyer to readoct only the interesting information which is estiraled to be about 10,000 worts per event cut of the three eilltion possible wres. Forcunately. this drastically reduces tha requireaents on the reecsit and pracessing systen.

\section{Systec: tonsideraticns}

The original IPC propasel described the use of 12] fast inc"s (I us airitizing li-a) astigrec :mese

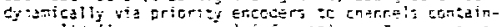

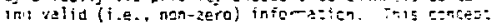

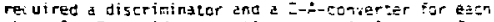
channel. To ewaid saturating a particular set of tult tiplexed channels, ic would be necesserj :o scrazle che inel to acdrase relationstips, so that sicrists in

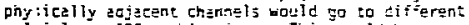
mull iplexer-mbl cominaticns. Inis would hiete required en additional "unseranbing step in the reegout systes and enerefore en - jitional s=t of data buffirs. This ecriplexity resuliet in tire stud of a teinetive schere:

Since the outputs fron the CCD's =re constent valuje levels for 50 is, an cbvice way :o digtitiz

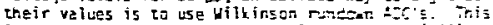

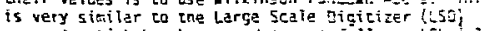
concept, which has been used stecess filly at Lis
eng el iewhere. Sirce the rem conerator and ine associlited logic can be shares setuesn remy enenrais,
LAWTENGE Estike]

Liviversity ef Culiñomiz

Eerieley, california 54720
- Tnis wort wes suppared by the Division of Fhysical Resezri] of the [epirtesent of Erergy unger Contrec: Ho. H-? $405-E M E-S g$. 
Fach ADC channel consis: cosentially only of one coppdrator dad one register. The stepllelty be this

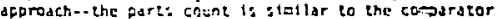

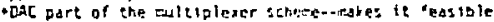
to supply one for Ger stgnal channel and to oigitire dil signals fros the CCD's. Detectton of valid inforration (i.e.. atolisude, inreshold) ther consists of coroaring two digital nueters, che from the ESC register and the other from a preset taresnoid register. ialid inforieticr is then pleced in en output buffer, which cen te rezdus, whlle the next digitization teise place.

The resolution ressiretents (a bit) for tre $=0 C$ are tictived by ara mesesslig for gartucle iten:ification and iract-centegr finding.

\section{Configureticn}

Wic decided to Dut ie fic chennels on ore bodrt.

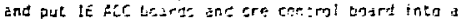

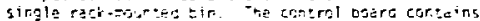
tha rato jererctor. the cloes dri ler, end also the line drivers end raceipors which refeive tha isc tata from the fib tosiss erid prodide the connection to the cecputer. Fiso. trratola inforetion for tin indiviciel aDr cichnsl is distrivuted frot the consuter to the ArC boerts sid the ceritrol baard. The crethots used ta distribute the rase end the clock pulses heve beer, discussed in earlier papers."

Since this version of the Lit conchpt relies heavily on registers, ccs: effectiveness dictates the use of ini-cust ragisters. Sinre the lawes: cose per bit is offered by pandon iccass locory (Pjit) chips, the first versian of the design (sndwn in fig. 2) was based on their use.

The voltege level fron the [C] is compared to a 41 is Ions Iincer rapp. Spenning the full signal aplitude range. A change of state in the cofperdtor output is synchronized to the clock, end shaped to are clack pulse width. In this clock pulse, a bit is written in the data line of the parcicular channel of the "hit-list" Row (ló hard $x$ if bit) end sinultaneous ly the stite of the cloct: ouncer is written into a "pulse-heigni" Ras (ló wora x 12 vit, enly 9 bits are used heral. After this aperetica a isti event counter is increfenisn, whese cuidut generetes the address for insise pi:T's.

After all channels nuta fired. the hi: list

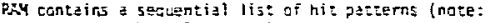
core than gre chanrel con regisol the 5 sze

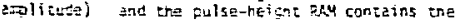
associated polse-neigin mater. The infaration in the phy's is not orteres in ensenel nueser sequence, but rather in ar a a i itude saguence. For readaut the cabe ast be reorcered eccoring to chunnel

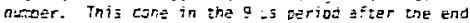
of tize $r \geqslant 0$.

The roordsring is done by looking with a =askable priority encoder at the outsuts oi tha bit lis: est Lo derive the cnannal nuter of una fired chanxels.

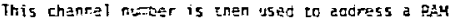
wich contzins the tnresingld inioration. IF tre pulse height is lacter tien tie threshold, it is wirten in:o the output fort, and the line correspending to the channel nutber iired is casked. Tinen eitist the ncat enennel is chented, or if there exs no orte urasked dis at the particular pulse neign: tha eient counter is decresented, the cast is reset, and the proxecure continued unit all pyuns naye been

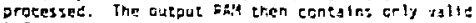
inforestion. with can be readoul curing tre neat il at cigleization sycle. In trits scheres the sern: ntmer of integrated ctrcules is used for resolutions betreen 5 and 12 bius. the cifference being only the nifeer of aucpuss used in the pulse hoiçnt. throchng.d.

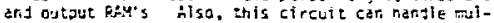
ciple hies in ont signd channel, with can hapotn, e.g. in tics digitizers. es licrig as they are separated by one or rore clack puises.

Tine disedrentage of the eletnod is ane gesterity ascociates witr. tre reortering. since tha lasa in $r$

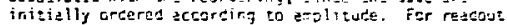
purposes howerar an ordering iccorcing to chenreil nuter is neeced. Inis could be cone eitner by us ing

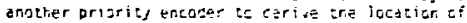
vald date in tre outpe: Fot or th arijgner regrce ing step. Eotn poseltilieles ir zrease ane nuter ot the

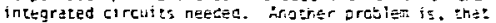

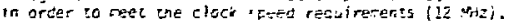

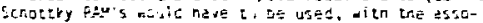
cizesd nigner doder dissibe:ien.

Therefore th our fina cesion, we nade crosen to use a-bit low egiwer schectiy reqister. IT's. wrich have tecore ayailable recently, anc to tre ore actitional flip flop jer anc cnennel to achiede the g-bi: resolution needec. The circuit is given in figs. and 4 . Again as in input conparazor cnances state. this chenge is symchronixed to the eleck. Ind tha current state of the cloc: culse cautier iz irritier. into a register cansisting of ar, $2-t i:$ tri-5t:teautput rejister and an editical fij fieg. iz tre end of the ramp. \pm 11 cranrels. which rere nis: chenged ere forcad to change, sa cinas "ateritions" eppeer at anplitude chennei $51 \mathrm{l}$.

Here no reordaring is necessarf, the contral logic steps through the contents of the fic register in a sequence of discending chanret river, cepares then with the eppropriate threshold. ard writes ties

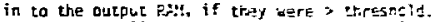
there was a valid event. it inerasents a telic avent counter. Ihis copressicn frocess eccurs ca all fir basds in parallel, so trat the conerea and cropessol

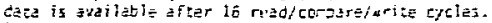
iata in the cuszut ofin's cen ther. te read gut in en.

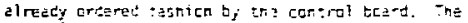

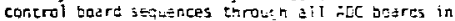
its bin, skipping the ories wich, have no valit cat?e (i.e.. when the vatid exent cainger is zere). I ist bin-skip fezture is also provicso to persit shipping a bin in one readowt cycle, if it certairs no valid date.

The threstalc psy's on the foC board rast be loaded fror tha computer. This can be ena by digitizing the input lavels witn no sigrals present, end Inser by writing a nu=ter greater erian titis nedsured $2 \cong r$ level" inco the threshold PFy's. Ihe inioretion irt particular chanrel can be supjesied by set:ins

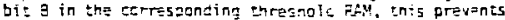

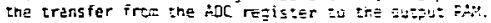

The advantaga of the register varsion is tis sirplicity of the date reduction logic, since all uperations asn ta cane by directly eddressina a jarti-

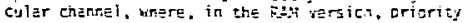
encoders üuse ba used. Heaver, the resoluting ci tie "register AfC is essenticlly linted ta 7 bits, beczusa rare bits oodld reguiro rore ic pjckices than

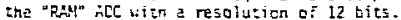


In addition. the register taplerentation connct tolerate aliple hits in one channel. suen as aignt be requires in tiee elgizizers.

We use a digitizer clock frequency of $12.5 \mathrm{HAz}$, which gives a saxiaus digitizing zize of 41 tis for 9 bics. Sir.ce the [CD slow clock rate is $10 \mathrm{kHz}$ (1.e.. $50 \mathrm{is} / \mathrm{s}$ lep) 9 is recain to reduce and reorter the datd. Osring tie first 40 is of the nexr CCO slow clock cycle, valia data fro the previous clack cycle are presented to the recous bus. Since only valic eate is treisent. the requiretanes on the reddout syster ere tinizizca.

\section{Conclustion}

We heve cesiggned a low-cost, rultichannel ado and reacout sysen, whith reets all the requirerents foosed by the ife celector. Ill signals in every chennel are etgitizes, stereby arofeing tra gitio culties 2550 cléted witi. to =uleiplexing of cany anilog signal ints ane coracen inc. Since the aplituce iriormeion is digitized b; the sere cevice. regaraless of its aralituce, there is oriy one caltbration necessar for each chennel. The diçical inforation is arzileble after a recsonably sirort tire $(41 ; 5)$, ene all further date processing can be cone with cigitel nuters. This allows elininetfon of fnulid inforazicr, i.e. . zeros, very early in the signi? proceising, and therefore meduces the deands on the readout syster. Ir shovid be passible then, to do "real tice- date processing with ficrooratessors on the steen of recuced data.

If faster integraced circuits ( the ECL) ere used the nimer of bies can be increased, or the digitizfing tice can be stortened.

This class of and and readout systen is well ratched to the rodarn generation of detectors, where ceny stgnel chentel have to be inspected in a short tire, but orily a fer provice valid infordacion.

\section{References}

i. D. R. Mygren end 4. K. Marx, Fhysics Today, Di 46-53, 0rcoser, iFiz.

2. E. Tazgan ent F. Rraten, IEgE Trans, Rugl, Sci,

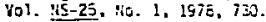

3. R. F. Altheus, F. A. Kirsten, K. L. Lee, 5. R. Dlson, L. J. Wuger end J. 4. Walverton, IEEE

Trans. Hucl. Sci.. Vol. 145-24, No. 1. 1977, 408.

f. R. 5. Aicheus, X. L. Lee, F. A. Kirsten and L. J. Waçnér. IEEE Trens. ducl. Sci.. Yol. US-Ż, Mo. I, 1977, 216.

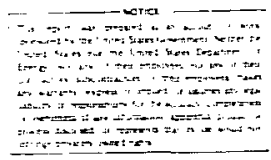




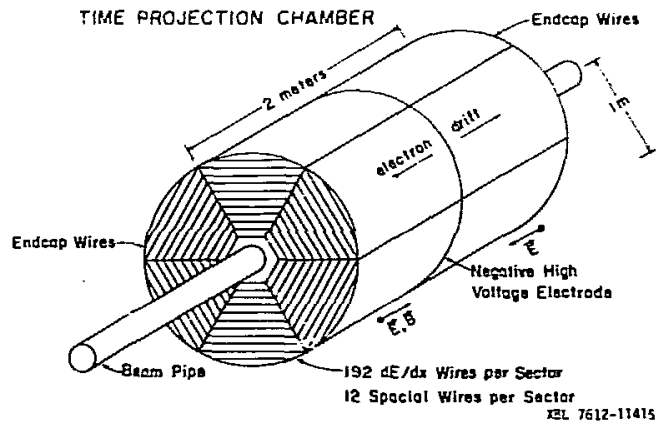

Fin. 1. Schenatic picture of the Time Prnjectinn Chamber. Charoed aarticles ornduced innization in the hinh iressure nas of the TPC. The innization electrons drifi toward the end-caps under the influence of the axial magnetic and electric itelds. Sense wires then multiolv this charne and the detec:or electronics are uset to measure the charne and its time of arrival. 


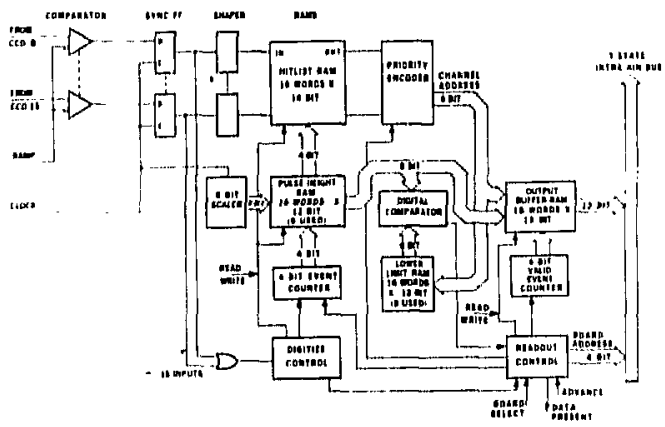

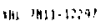

Fin. 2. Partial schematic of the first verston of the dinitizar. The levels from t'ie CCS's are comnared to $A$ cormon rano. The crossinn time of the ramn and the level is sunchrollizad to the cominon clock, and the dinftize control stores, it the Aunroorlate nulse heinht, the hit list rast. After the and of the ramn the roatout control cominares the information from the difforent channels to the corrosoondinn lower level. and writes it Into the outnut huffer RAN. The further readout is siritior to Fin. n. 
LQL-กI 3E.

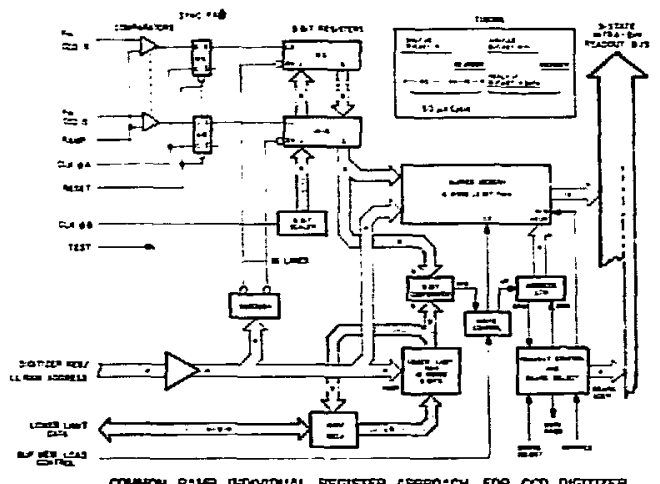

IST TIT

Fin. 3. Partial schematic of the remister yersion of the dijitizer. The crossinn of the cormon rame with with levels from the cCo's are svachranizer to the clock, and the nulse heirht number is urit:en into the reaisters. After the and of the ram the readout contral senuances throuph all if raristars. and writes their content into the outnut huffer menory. This buffer is then read out unter the control board of Fin. 4. 


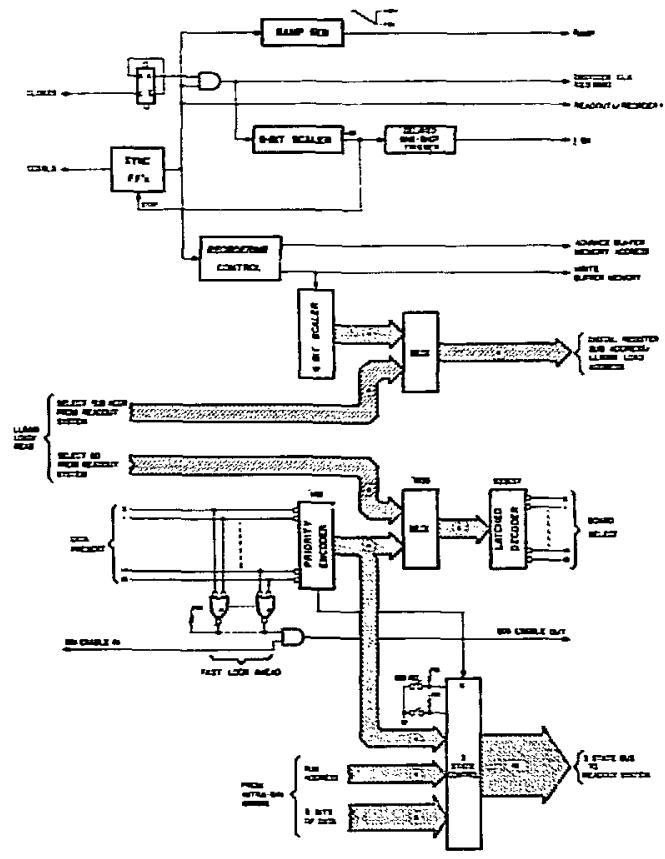

른 $\pi S-50 \pi$

Fin. 4. Partial sehematic of the contro? coard of the second verision of tie dinitizer. This bnard nenerates the comon rang, comon clock and the nulses which control the reordering and read out. The 'data present' lines from the digitizer board are used to select only the toards which have non-zero data for readout. 